\title{
Pengaruh Aplikasi Pupuk Organik dan Pestisida Organik terhadap Produktivitas Terung (Solanum melongena) dan Tingkat Bahaya Erosi
}

\section{The Influence of Organic Fertilizer and Organic Pesticide Application On Productivity of Eggplant (Solanum melongena) and Erosion Risk Level}

\author{
Idah Andriyani ${ }^{1 凶}$, Fiona Cahya Patricia $^{\mathbf{1}}$ \\ ${ }^{1}$ Program Studi Teknik Pertanian, Fakultas Teknologi Pertanian, Universitas Jember \\ ${ }^{\square}$ Komunikasi Penulis, email: idahandriyani32@gmail.com \\ DOI:http://dx.doi.org/10.23960/jtep-l.v10i4.515-529 \\ Naskah ini diterima pada 29 Juli 2020; revisi pada 21 Mei 2021; \\ disetujui untuk dipublikasikan pada 9 Desember 2021
}

\begin{abstract}
This study aims to analyze the effects of the use of organic fertilizers and organic pesticides on eggplant productivity and the level of erosion hazards that occur on these intensive agricultural lands. The use of organic fertilizers and pesticides is expected to improve soil quality which in turn will increase crop productivity and reduce erosion yield. Randomized block design (RBD) was used with a combination of dosage treatment of organic fertilizers $(P)$ and organic pesticides (B). The dosages of organic fertilizers used were: $0 \mathrm{~kg} / \mathrm{bed}(P 1 / \mathrm{control}), 1 \mathrm{~kg} / \mathrm{bed}(P 2)$, $1.5 \mathrm{~kg} / \mathrm{bed}(\mathrm{P3})$ and $2 \mathrm{~kg} / \mathrm{bed}(\mathrm{P} 4)$. The doses of pesticides used were chemical pesticides $2 \mathrm{ml} /$ liter (B1/control), organic pesticides $7 \mathrm{ml} /$ liter (B2), $9 \mathrm{ml} /$ liter (B3) and $11 \mathrm{ml} /$ liter (B4). The highest productivity research results were obtained from combination of P4B1 (fertilizer dose $2 \mathrm{~kg} / \mathrm{bed}+$ chemical pesticides). This shows that organic fertilizers and pesticides can increase plant productivity. However, organic pesticides have not been able to reduce pest attacks during the fertilization phase. On the other hand, the rate of erosion has actually increased which is not significantly different between the use of organic fertilizers and chemical fertilizers. This is due to the increase in the content of organic matter and changes in soil texture which cause the soil to become loose and crumb so that it is more easily eroded. Thus the use of organic fertilizers and pesticides can be used continuously in intensive agriculture but must be accompanied by other conservation activities to reduce the erosion yield. In addition, it is necessary to develop more effective organic pesticides to eradicate pests and plant diseases.
\end{abstract}

Keywords: erosion, eggplant plants, intensive agriculture, organic fertilizer, organic pesticide.

\begin{abstract}
ABSTRAK
Penelitian ini bertujuan untuk menganalisis pengaruh penggunaan pupuk organik dan pestisida organik terhadap produktivitas tanaman terung dan tingkat bahaya erosi yang terjadi pada lahan pertanian intensif tersebut Penelitian dilakukan pada pertanian intensif tanaman terung di Dusun Pangepok Desa Sucopangepok Kecamatan Jelbuk Kabupaten Jember yang dianggap mewakili kondisi pertanian intensif di hulu sub-DAS Arjasa. Rancangan Acak Kelompok (RAK) digunakan dengan kombinasi perlakuan dosis pupuk organik (P) dan pestisida organik (B). Dosis pupuk organik yang digunakan yaitu: $0 \mathrm{~kg} /$ bedeng (P1/kontrol), $1 \mathrm{~kg} / \mathrm{bedeng}(\mathrm{P} 2), 1,5 \mathrm{~kg} /$ bedeng (P3) dan $2 \mathrm{~kg} /$ bedeng (P4). Dosis pestisida yang digunakan yaitu pestisida kimia $2 \mathrm{ml} / \mathrm{liter}$ (B1/kontrol), pestisida organik $7 \mathrm{ml} /$ liter (B2), $9 \mathrm{ml} /$ liter (B3) dan $11 \mathrm{ml} /$ liter (B4). Hasil penelitian menunjukan produktivitas tertinggi diperoleh dari perlakukan P4B1 (dosis pupuk 2kg/bedeng + pestisida kimia). Hal ini menunjukan bahwa pupuk dan pestisida organik mampu meningkatkan produktivitas tanaman. Namun pestisida organik belum mampu menurunkan serangan hama pada fase pembuahan. Disisi lain laju erosi justru mengalami peningkatan yang tidak berbeda nyata secara signifikan antara penggunaan pupuk organik dan pupuk kimia. Hal ini disebabkan karena meningkatnya kandungan bahan organik dan perubahan tekstur tanah yang menyebabkan tanah menjadi gembur dan remah seingga lebih mudah tererosi. Dengan demikian penggunaan pupuk dan pestisida organik dapat dipergunakan secara terus menerus pada pertanian intensif namun harus dibarengi dengan kegiatan konservasi yang lain untuk mengurungi laju erosi. Selain itu perlu dikembangkan pestisida organik yang lebih efektif untuk membasmi hama dan penyakit tanaman.
\end{abstract}

Kata Kunci : erosi, pertanian intensif, pestisida organik, pupuk organik, tanaman terung 


\section{PENDAHULUAN}

Daerah Aliran Sungai (DAS) merupakan wilayah daratan yang menjadi satu kesatuan dengan sungai dan anak sungainya. Fungsi DAS untuk menampung, menyimpan dan mengalirkan air yang berasal dari curah hujan ke danau atau laut (UU No. 7 Tahun 2004). Bagian dari DAS yang menerima air hujan dan mengalirkannya melalui anak sungai ke sungai utama adalah Sub DAS. Eksploitasi Sub DAS dapat menyebabkan bajir di musim hujan dan kekeringan di musim kemarau, penurunan debit sungai, erosi, sedimentasi dan tanah longsor (Andriyani et al, 2019).

Erosi merupakan peristiwa pindahnya atau terangkutnya tanah atau bagian tanah dari suatu tempat ke tempat lain oleh media alami berupa air dan angin. Pada lokasi terjadinya erosi, terjadi penurunan kualitas tanah berupa hilangnya lapisan tanah pada horizon 0 yang terdiri dari bahan organik yang sangat diperlukan untuk pertumbuhan tanaman, sedangkan didaerah hilir lapisan tanah yang tererosi bisa menjadi sedimentasi (Andriyani et al., 2019). Selain erosi, degradasi lahan juga disebabkan oleh alih fungsi lahan, pencemaran, dan penggunaan pupuk dan pestisida kimia yang berlebihan atau tidak tepat (Wahyunto dan Dariah, 2014).

Sungai Bedadung adalah salah satu sungai terbesar di Kabupaten Jember yang berada pada DAS Bedadung hilir dan melewati ibu kota kabupaten dengan panjang 46.875 meter dan mampu mengairi lahan sawah seluas $93.000 \mathrm{Ha}$. Sub DAS Arjasa merupakan bagian dari DAS Bedadung. Beberapa tahun terakhir pada saat musim penghujan sering terjadi banjir dan tanah longsor pada wilayah-wilayah tertentu. Salah satu faktor penyebabnya adalah pemanfaatan lahan yang tidak sesuai dan vegetasi tanaman ditebang, sehingga resapan air berkurang menyebabkan erosi dan peningkatan sedimentasi di aliran sungai (Ardani, 2020). Kondisi DAS dipengaruhi oleh bagian hulu yang menjadi daerah tangkapan serta resapan air. Daerah resapan berfungsi untuk menampung air hujan yang turun sehingga memiliki peran penting sebagai pengendali banjir pada musim hujan dan kekeringan pada musim kemarau. (Santoso et al. 2013).
Dari hasil survey pendahuluan di Sub DAS Arjasa diperoleh hasil bahwa sebagian besar lahan pertanian disini digunakan untuk pertanian intensif untuk tanaman semusim seperti, cabai, tomat, terung, jagung dan padi. Pertanian intensif memiliki dampak negatif bagi ekosistem karena intensitas pemakaian pupuk kimia terus meningkat dari waktu ke waktu (Dewanto et al., 2013). Penggunaan pupuk kimia dalam jangka panjang mangakibatkan kandungan bahan organik tanah menurun, struktur tanah rusak dan pencemaran lingkungan. Jika hal tersebut terus berlanjut akan menurunkan kualitas tanah dan kelestarian lingkungan.

Hasil evaluasi tingkat bahaya erosi pada sub DAS Arjasa dengan menggunakan data tanah pengukuran di lapang pada lahan pertanian, diperoleh hasil tingkat bahaya erosi sangat berat sedangkan menggunakan peta tanah memperoleh kondisi berat (Ardani, 2020). Hal ini menunjukan bahwa telah terjadi kerusakan tanah yang menyebabkan nilai erodibilitas tanah meningkat. Oleh karena itu pada lahan pertanian intensif perlu dilakukan perbaikan kulitas tanah yang mampu meningkatkan produktifitas tanaman dan mengurangi laju erosi.

Perbaikan kualitas fisik tanah dapat dilakukan dengan pemupukan dan merehabilitasi tanah baik secara fisik, kimia, maupun biologi (Adnyana, 2011). Penggunaan pupuk organik dengan dosis yang tepat dan dikombinasikan dengan pupuk kimia mampu meningkatkan produktivitas tanah (Simanjuntak, 2013). Penelitian ini bertujuan untuk mengetahui pengaruh pemberian pupuk dan pestisida oragnik terhadap produktifitas tanaman dan pengurangan laju erosi pada lahan perkebunan terung.

\section{BAHAN DAN METODE}

Penelitian dilakukan tanggal 25 Agustus sampai 24 Desember 2019. Lokasi penelitian berada di kawasan pertanian bagian hulu Sub DAS Arjasa yang bertempat di Dusun Pangepok Desa Sucopangepok Kecamatan Jelbuk Kabupaten Jember dengan letak geografis antara -8,0526 S sampai 113,7369 E seperti pada Gambar 1. Luas Sub DAS Arjasa yaitu $15 \mathrm{~km}^{2}$. Penggunaan lahan 


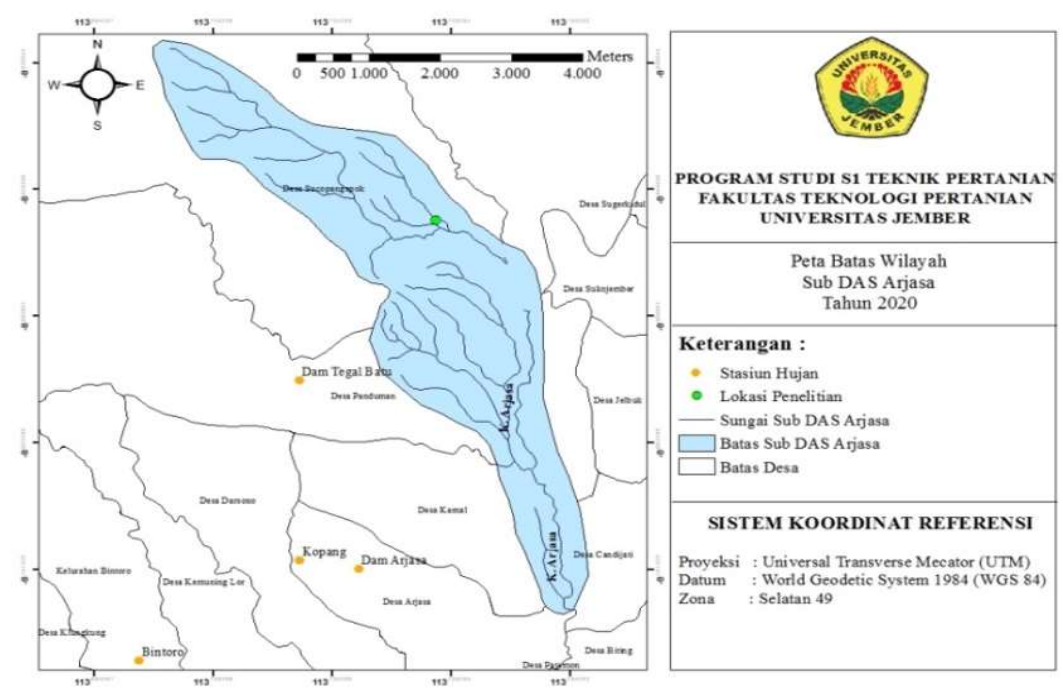

Gambar 1. Batas Sub Das Arjasa

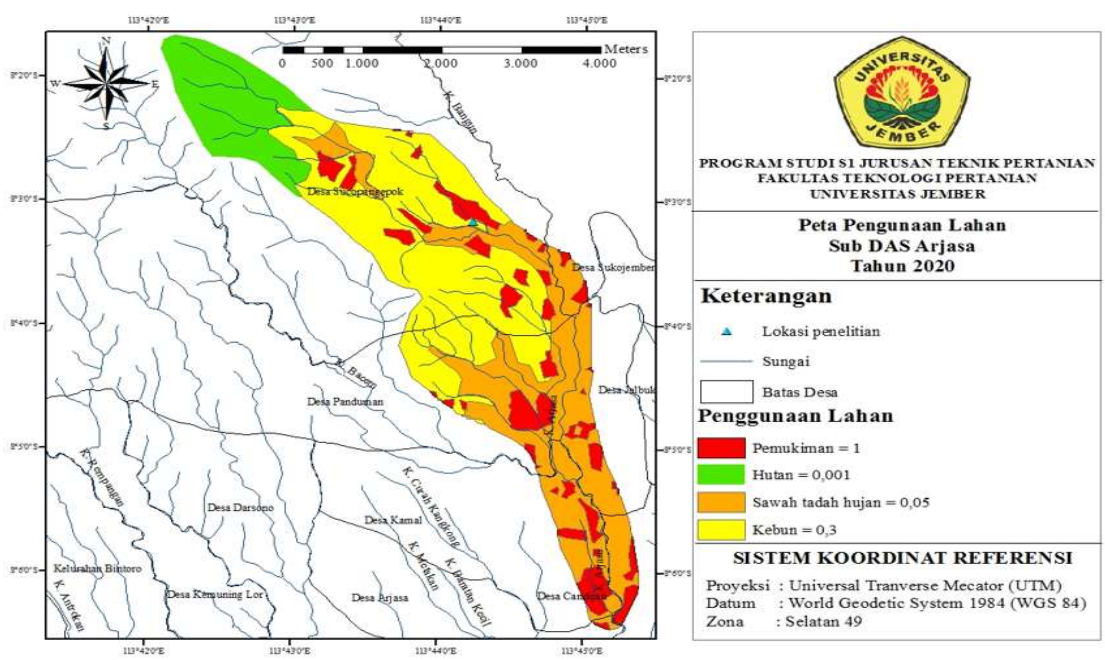

Gambar 2. Peta Penggunaan Lahan di Sub DAS Arjasa

di wilayah Sub DAS Arjasa didominasi oleh kebun dengan luas 602 hektare atau $6 \mathrm{~km}^{2}$ dari luas total. Peta tataguna lahan Sub DAS Arjasa disajikan pada Gambar 2.

2.1. Analisis Produktivitas Tanaman Terung Analisis produktivitas tanaman terung terdiri dari pengamatan tinggi tanaman, jumlah helai daun, dan hasil panen . dimulai dengan pengolahan tanah disertai dengan pembuatan bedeng yang kemudian dilakukan pengaplikasian pupuk organik organema dan dilakukan penanaman tanaman terung. Setiap minggu dilakukan pengukuran jumlah daun dan tinggi tanaman hingga tanaman siap panen. Data tinggi tanaman dan jumlah daun yang diperoleh dianalisis menggunakan Anova dua arah untuk mengetahui pengaruh pemberian dosis pupuk organik dan pestisida organik terhadap produktivitas tanaman terung.

Rancangan percobaan yang digunakan pada penelitian ini menggunakan Rancangan Acak Kelompok (RAK) dengan 2 faktor yaitu konsentrasi pupuk (P) dan pestisida organik (B). Masing-masing faktor terdapat 4 dosis perlakuan yang berbeda yang diaplikasikan pada tiap bedeng sehingga terdapat 16 bedeng. Pada setiap bedeng terdapat 8 tanaman ( 5 tanaman utama dan 3 tanaman sulaman). Luas setiap bedeng yaitu $2,31 \mathrm{~m}^{2}$ dan luas lahan yang dibutuhkan untuk 16 bedeng sebesar $58,41 \mathrm{~m}^{2}$. Denah rancangan percobaan disajikan pada Gambar 3 . Berikut dosis pupuk yang digunakan dalam penelitian: 


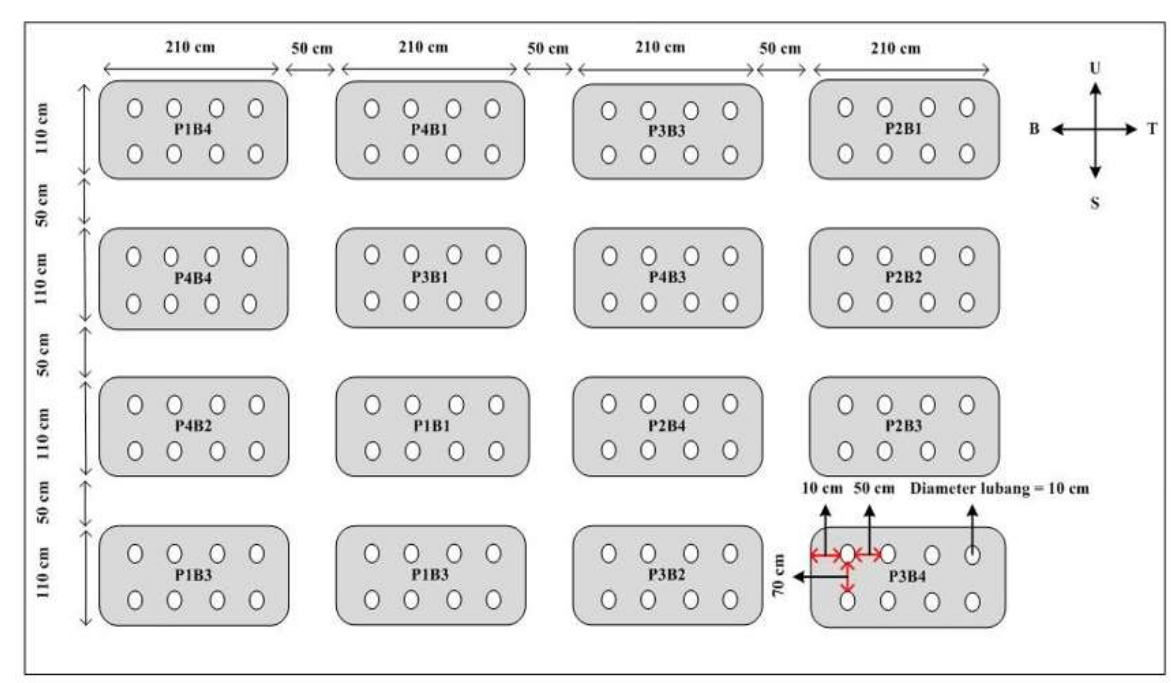

Gambar 3. Denah Rancangan Percobaan

1.P1 = tanpa pupuk organik (kontrol, sesuai dengan perawatan yang dilakukan petani sekitar)

$2 . P 2=$ pemberian pupuk organik $1 \mathrm{~kg}(0,125 \mathrm{~kg}$ pupuk organik/tanaman)

3.P3 = pemberian pupuk organik $1,5 \mathrm{~kg}(0,18 \mathrm{~kg}$ pupuk organik/tanaman)

$4 . \mathrm{P} 4=$ pemberian pupuk organik $2 \mathrm{~kg}(0,25 \mathrm{~kg}$ pupuk organik/tanaman)

Sedangkan dosis pestisida organik yang digunakan yaitu :

1.B1 = pestisida kimia sebanyak $2 \mathrm{ml} /$ liter (volume semprot 7,8 $\mathrm{ml} /$ tanaman)

2. $\mathrm{B} 2$ = pestisida organik $7 \mathrm{ml} /$ liter (volume semprot 7,8 ml/tanaman)

$3 . \mathrm{B} 3$ = pestisida organik $9 \mathrm{ml} /$ liter (volume semprot 7,8 ml/tanaman)

$4 . \mathrm{B} 4=$ pestisida organik $11 \mathrm{ml} /$ liter (volume semprot 7,8 $\mathrm{ml} /$ tanaman)

\subsection{Analisis Kualitas Tanah}

Pada masing-masing petak percobaan dilakukan pengukuran kualitas tanah yang berupa analisis tekstur, struktur, bahan organik dan permeabilitas tanah. Sampel tanah yang digunakan yaitu sampel tanah terusik (untuk analisis tekstur, struktur dan bahan organik) dan sampel tanah tak terusik (untuk analisis permeabilitas).

\subsubsection{Analisis Tekstur Tanah}

Analisis tekstur dilakukan dengan metode Hidrometer karena lebih praktis, sederhana dan cepat. Persentase pasir $(P)$, debu $(D)$, dan liat $(L)$ dihitung dengan Persamaan 1, 2 dan 3 berikut (Hanafiah, 2014):

$$
\begin{aligned}
& P=100-\frac{\{(R 1-2 B 1)+0,36(T 1-20)\} \times(100+M)}{W} \\
& L=\frac{\{(R 2-B 2)+0,36(T 2-20)\} \times(100+M)}{W} \\
& D=100-\mathrm{P}-\mathrm{L}
\end{aligned}
$$

dimana R1 merupakan pembacaan pertama hidrometer pada contoh, R2 merupakan pembacaan kedua hidrometer pada contoh, B1 merupakan pembacaan pertama hidrometer pada blanko, B2 merupakan pembacaan kedua hidrometer pada blanko, T1 merupakan pembacaan pertama suhu, T2 merupakan pembacaan kedua suhu, 0,36 merupakan faktor koreksi hidrometer, 20 merupakan suhu kalibrasi hidrometer, $\mathrm{W}$ merupakan berat kering contoh tanah yang digunakan analisis, dan M merupakan \% contoh tanah kering udara.

\subsubsection{Analisis Struktur Tanah}

Analisis struktur dilakukan menggunakan sampel tanah terusik, kemudian mengambil gumpalan tanah yang dibatasi dengan agregat utuh kemudian diamati bentuk dan ukuran tanah tersebut serta mengukur diameter tanah menggunakan penggaris.

\subsubsection{Permeabilitas}

Nilai permeabilitas digunakan untuk menganalisis kemampuan tanah untuk meloloskan air. Permeabilitas tanah dihitung menggunakan Persamaan 4 (Arsyad, 1989). 


$$
K=\frac{(Q \cdot L)}{(H \cdot A . t)}
$$

dimana K merupakan permeabilitas ( $\mathrm{cm} / \mathrm{jam})$, Q merupakan jumlah air yang keluar atau tertampung ( $\mathrm{ml})$, L merupakan tinggi ring $(\mathrm{cm})$, $\mathrm{H}$ merupakan tinggi paralon (cm), A merupakan luas permukaan tanah $(\mathrm{cm})$, dan $\mathrm{t}$ merupakan waktu (jam).

\subsubsection{Analisis Bahan Organik Tanah}

Pengukuran bahan organik dilakukan menggunakan metode Walkey \& Black dengan menghitung nilai C-organik terlebih dahulu. Karbon organik dalam sampel tanah dioksidasi oleh dikromat dalam suasana asam. Krom III yang terbentuk setara dengan $\mathrm{C}$ organik yang teroksidasi kemudian diukur secara spektrometri menggunakan Persamaan 5 (Balai Penelitian Tanah, 2009).

$$
\text { C-organik }=\frac{\frac{m l e k s t r a k}{\text { grcontoh }} \times \text { ppm kurva } \times f k \times f p}{10.000}
$$

dimana ppm kurva merupakan kadar contoh yang didapat dari kurva antara kadar deret standart dengan pembacaannya setelah dikoreksi blanko, $f p$ merupakan faktor pengenceran, $f k$ merupakan faktor koreksi kadar air $=100 /(100-$ kadar air $)$, dan 10.000 merupakan konversi dari \% ke ppm.

Setelah diperoleh nilai C-organik, dilakukan penghitungan bahan organik tanah menggunakan Persamaan 6 berikut (Arsyad, 2010).

$$
\text { B-organik (\%) = 100/58 } \times \text { C-organik (\%) }
$$

dimana 100/58 adalah faktor Van Bemmelen.

\subsection{Perhitungan Laju Erosi Menggunakan Metode USLE}

Tingkat bahaya erosi dapat dihitung menggunakan metode USLE (Universal Soil Loss Equation). Dimana metode USLE adalah salah satu metode pendugaan erosi yang cukup baik dipergunaakan unruk prediksi erosi pada level perkebunan (Andriyani et al., 2017). Perhitungan prediksi erosi dilakukan menggunakan metode USLE dengan Persamaan 7 berikut (Arsyad, 2010).

$$
A=R \times K \times L S \times C \times P
$$

a) Faktor Erosivitas Hujan $(R)$

Data curah hujan yang digunakan yaitu data curah hujan tahun 1999-2018 dari empatstasiun hujan terdekat dari Sub DAS Arjasa yaitu Kopang, Tegal Batu, Bintoro, Dam Arjasa. Menurut (Arsyad, 2010) erosivitas $(R)$ merupakan kemampuan hujan untuk menyebabkan erosi, yang diperoleh dari penjumlahan nilai indeks erosi hujan bulanan yang dihitung menggunakan Persamaan 8 berikut.

$$
R=10,80+4,15 \mathrm{CH}
$$

dimana $R$ merupakan indeks erosivitas bulanan, dan $\mathrm{CH}$ merupakan curah hujan bulanan $(\mathrm{cm} /$ tahun). Nilai erosivitas dari 5 stasiun hujan diinput pada layer stasiun hujan menggunakan software ArcGIS kemudian dilakukan interpolasi menggunakan metode IDW (Inverse Distance Weighting) (Andriyani et al., 2020).

b) Faktor Erodibilitas Tanah (K)

Faktor erodibilitas merupakan kepekaan tanah terhadap erosi. Menurut Arsyad (2010), USDA Nomograph digunakan untuk menentukan nilai erodibilitas, dari sampel tanah yang diambil.

c) Faktor Panjang dan Kemiringan Lereng ( $L S$ ) Pengukuran faktor panjang menggunakan roll meter dan kemiringan lereng menggunakan abney level. Nilai faktor S dalam metode USLE dihitung menggunakan Persamaan 9 dan 10 berikut (Arsyad, 2010).

$$
\begin{aligned}
& S=65,41 \operatorname{Sin}^{2} \theta+4,56 \operatorname{Sin}^{2} \theta+0,065 \\
& L S=\sqrt{x}\left(0,0138+0,00965 S+0,00138 S^{2}\right)
\end{aligned}
$$

dimana $\theta$ merupakan sudut lereng (derajat), $x$ merupakan panjang lereng $(\mathrm{m})$, dan $S$ merupakan kecuraman lereng (\%).

d) Faktor Pengelolaan Tanaman dan Tindakan Konservasi Tanah $(C P)$

Faktor pengelolaan tanaman (C) yang dipergunakan adalah budidaya tanaman Terung dan tindakan konservasi tanah $(P)$ yang ada dilokasi kebun adalah adanya pembuatan teras sederhana pada lokasi-lokasi kebun penelitian. Masing-masing luasan kebun adalah seluas $20 \mathrm{x}$ 20 meter. 


\section{HASIL DAN PEMBAHASAN}

\subsection{Produktivitas Tanaman Terung}

Analisis produktivitas dilakukan dengan mengamati tinggi tanaman terung $(\mathrm{cm})$, jumlah daun (helai) yang dilakukan selama 10 minggu dimulai dari minggu ke-0 atau pada saat penanaman sampai minggu ke- 9 atau pada masa panen buah pertama (gram). Pengambilan data dilakukan setiap satu minggu sekali pada saat pagi hari.

Hasil analisis uji statistik Liliefors untuk tinggi tanaman menunjukkan $L_{\text {hitung }}(0,058)<L_{\text {tabel }}$ $(0,099)$ dan untuk data jumlah daun diperoleh $L_{\text {hitung }}(0,096)<L_{\text {tabel }}(0,099)$ yang berarti data tinggi tanaman dan jumlah daun berdistribusi normal dapat diuji menggunakan Anova dua arah. Hasil analisis uji Anova dua arah dengan taraf 5\% disajikan pada Tabel 1 berikut.

Berdasarkan hasil analisis anova dua arah untuk sumber data tinggi tanaman diperoleh nilai dari sumber keragaman dosis pupuk organik yaitu nilai $\mathrm{F}$ hitung $>\mathrm{F}$ tabel sehingga $\mathrm{H}_{0}$ ditolak dan $\mathrm{H}_{1}$ diterima. Hasil tersebut menunjukkan bahwa tedapat pengaruh yang nyata antar perlakuan dosis pupuk organik (P1, P2, P3 dan P4) terhadap tinggi tanaman terung. Sedangkan untuk sumber data jumlah daun diperoleh nilai dari sumber.

keragaman dosis pupuk organik dan interaksi yaitu nilai $\mathrm{F}$ hitung $>\mathrm{F}$ tabel. Hasil tersebut menunjukkan bahwa tedapat pengaruh yang

Tabel 1. Analisis Uji Statistik Anova Dua Arah

\begin{tabular}{|c|c|c|c|c|c|c|}
\hline Sumber Data & $\begin{array}{c}\text { Sumber } \\
\text { Keragaman }\end{array}$ & $\begin{array}{l}\text { Jumlah } \\
\text { Kuadrat }\end{array}$ & $\begin{array}{c}\text { Derajat } \\
\text { Bebas }\end{array}$ & $\begin{array}{c}\text { Kuadrat } \\
\text { Tengah }\end{array}$ & $\begin{array}{c}\mathbf{F} \\
\text { Hitung }\end{array}$ & F Tabel \\
\hline \multirow{5}{*}{$\begin{array}{c}\text { Tinggi } \\
\text { Tanaman }(\mathrm{Cm})\end{array}$} & Pupuk organik & 18,35 & 3 & 6,12 & 19,37 & 2,75 \\
\hline & Pestisida & 0,96 & 3 & 0,32 & 1,01 & 2,75 \\
\hline & Interaksi & 2,11 & 9 & 0,23 & 0,74 & 2,03 \\
\hline & Galat/Error & 20,21 & 64 & 0,32 & & \\
\hline & Total & 41,62 & 79 & & & \\
\hline \multirow{5}{*}{$\begin{array}{l}\text { Jumlah Daun } \\
\text { (lembar) }\end{array}$} & Pupuk organik & 0,53 & 3 & 0,18 & 5,45 & 2,75 \\
\hline & Pestisida & 0,12 & 3 & 0,04 & 1,21 & 2,75 \\
\hline & Interaksi & 0,85 & 9 & 0,09 & 2,93 & 2,03 \\
\hline & Galat/Error & 2,07 & 64 & 0,03 & & \\
\hline & Total & 3,58 & 79 & & & \\
\hline
\end{tabular}

Tabel 2. Analisis Uji Duncan pada Kombinasi Dua Faktor

\begin{tabular}{ccc}
\hline Perlakuan & Rata-Rata Tinggi Tanaman (cm) & Rata-Rata Jumlah Daun (lembar) \\
\hline P1B1 & 4,20 abcde & 1,07 cdefghijklm \\
P1B2 & $3,96 \mathrm{abc}$ & $0,67 \mathrm{a}$ \\
P1B3 & $3,89 \mathrm{ab}$ & $0,87 \mathrm{abcde}$ \\
P1B4 & $3,74 \mathrm{a}$ & $0,91 \mathrm{bcdef}$ \\
P2B1 & 5,1 defghijkl & $0,73 \mathrm{ab}$ \\
P2B2 & 5,15 defghijklm & $0,93 \mathrm{bcdefghi}$ \\
P2B3 & 5,21 efghijklmno & 1,00 bcdefghijk \\
P2B4 & 4,86 cdefghij & 0,91 bcdefg \\
P3B1 & 4,22 abcdef & 1,02 cdefghijkl \\
P3B2 & 4,85 cdefghi & 0,95 bcdefghij \\
P3B3 & 4,62 bcdefg & 0,78 abc \\
P3B4 & 4,14 abcd & 0,84 abcd \\
P4B1 & 4,85 cdefghi & 1,16 efghijklmno \\
P4B2 & 5,20 efghijklmn & 1,13 efghijklmno \\
P4B3 & 5,08 defghijk & 0,91 bcdefgh \\
P4B4 & 5,26 fghijklmno & 1,11 defghijklmn \\
\hline
\end{tabular}

Keterangan : Angka-angka yang diikuti huruf yang sama diartikan tidak berbeda nyata menurut uji Duncan pada taraf nyata $(\alpha) 0,05$. 
nyata antar perlakuan dosis pupuk organik (P1, P2, P3 dan P4) terhadap jumlah daun terung. Kemudian, dilakukan uji lanjutan menggunakan uji Duncan untuk mengetahui perbedaan antar perlakuan pupuk organik. Hasil uji Duncan dapat dilihat pada Tabel 2 .

Berdasarkan Tabel 2 dapat diketahui bahwa setelah dilakukan uji lanjutan pemberian pupuk organik dan pestisida organik berpengaruh nyata terhadap pertumbuhan tinggi tanaman dan jumlah daun terung. Hasil analisis uji Anova pada tinggi tanaman menunjukkan tidak terdapat interaksi antara pupuk organik dengan pestisida yang berarti faktor tersebut tidak saling mempengaruhi tinggi tanaman, yang dapat dilihat dari perlakuan P4B4 dan P2B3 yang berpengaruh besar serta memiliki notasi akhir yang hampir sama "fghijklmno" dan "efghijklmno" yang berbeda nyata dengan perlakuan P1B4. Hasil analisis uji Anova pada jumlah daun menunjukkan adanya interaksi antara kombinasi pupuk organik dengan pestisida yang ditunjukkan pada perlakuan P4B1 dengan rerata tertinggi. Hasil rata-rata data tinggi tanaman akan ditampilkan dalam Gambar 4.

Pertumbuhan tinggi tanaman yang optimum pada P4B4 dengan perlakuan $2 \mathrm{~kg}$ pupuk organik dan $11 \mathrm{ml}$ pestisida organik dengan nilai ratarata tinggi minggu ke-9 $54 \mathrm{~cm}$ sedangkan pertumbuhan terendah pada $\mathrm{P} 1 \mathrm{~B} 4$ dengan perlakuan kontrol dengan niai rata-rata tinggi tanaman $40 \mathrm{~cm}$ yang disebabkan kurangnya ketersediaan unsur hara yang dibutuhkan tanaman. Menurut Kartasapoetra dan Sutejo
(1991) kekurangan unsur hara mikro makro dapat menghambat pertumbuhan tanaman serta hasil panen. Pemberian pupuk organik dapat memperbaiki struktur tanah menjadi lebih lepas, merangsang pertumbuhan akar dan meningkan daya ikat serta daya serapnya sehingga kebutuhan air tanaman dapat terpenuhi.

\subsubsection{Jumlah Daun Terung}

Analisis jumlah daun tanaman menggunakan 5 data jumlah daun tanaman pada setiap bedeng. Kemudian, dari kelima data tanaman tersebut dihitung rata-rata setiap minggunya. Hasil ratarata jumlah daun tanaman akan ditampilkan dalam Gambar 5.

Pada awal minggu awal pemindahan bibit ke kebun, jumlah daun mengalami penurunan karena adanya rontok daun akibat adaptasi bibit dari kebun bibit ke kebun percobaan. Pertumbuhan jumlah daun yang optimum pada perlakuan P4B4 dengan nilai rata-rata jumlah daun minggu ke-9 14,6 helai. Menurut Lakitan (2011) unsur hara $\mathrm{N}$ berpengaruh pada pertumbuhan dan perkembangan daun. Kadar N yang tinggi akan menghasilkan daun yang banyak dan lebar. Pertumbuhan terendah pada perlakuan P2B3 dengan nilai rata-rata jumlah daun minggu ke-9 11,4 helai. Pada minggu ke-9 rata-rata jumlah daun pada tiap perlakuan cenderung tetap karena proses pembungaan, sehingga tanaman cenderung mengalami hambatan dalam pertumbuhan vegetatif (pembentukan tunas dan daun) (Muldiana dan Rosidana, 2017).

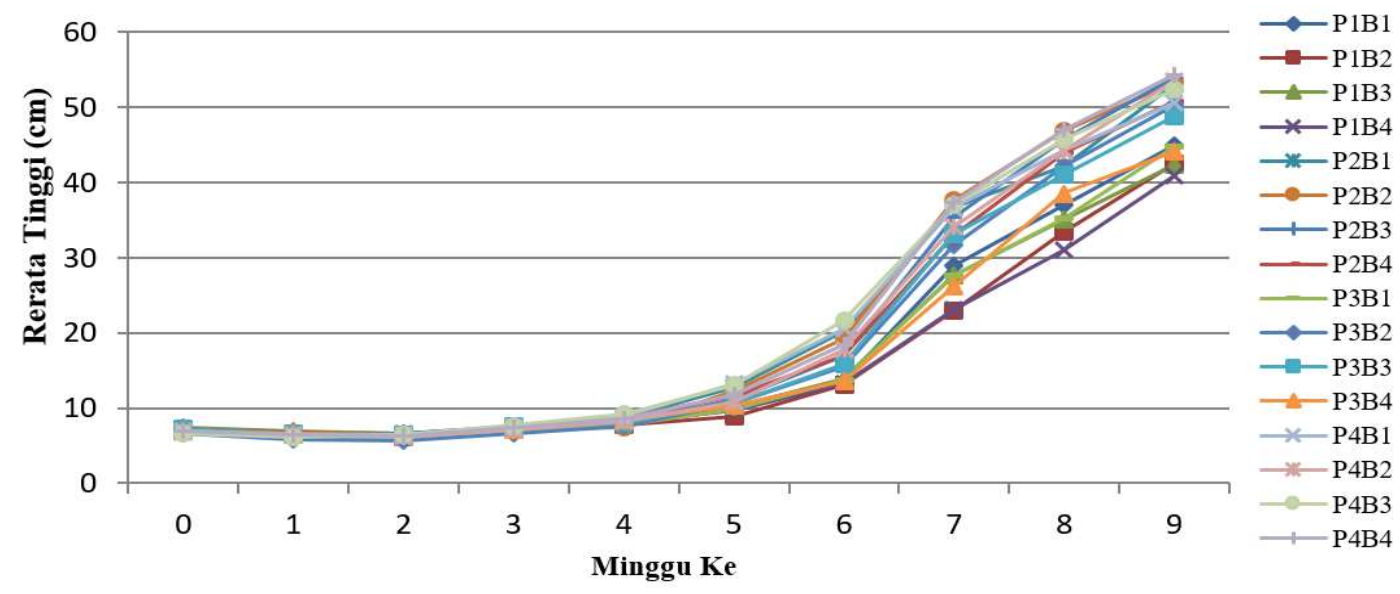

Gambar 4. Grafik Pola Pertumbuhan Tinggi Tanaman Terung Berdasarkan Perlakuan Pupuk Organik dan Pestisida 


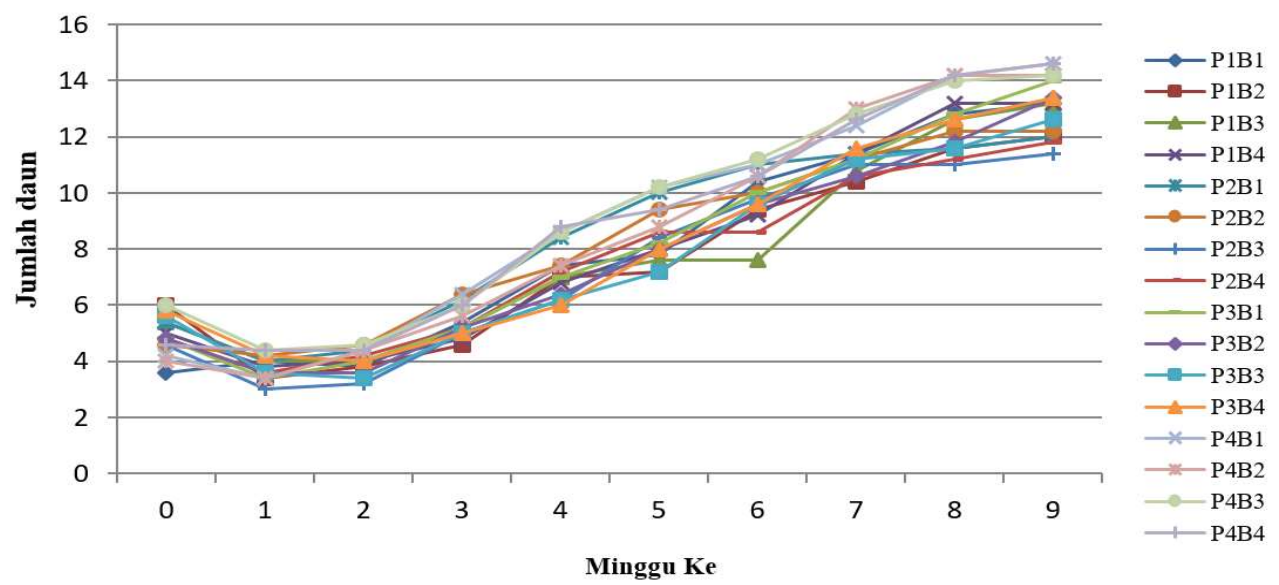

Gambar 5. Grafik Pola Pertumbuhan Jumlah Daun Tanaman Terung Berdasarkan Perlakuan Pupuk Organik dan Pestisida

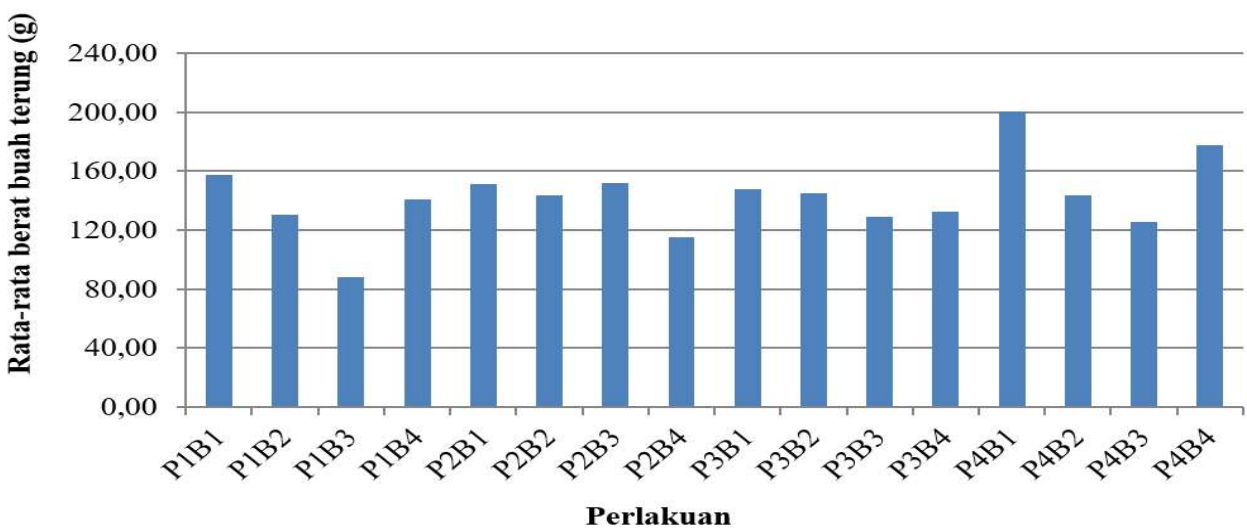

Gambar 6. Rata-rata Hasil Panen Pertama Terung

Pemanenan buah terung, dilakukan disaat panen pertama dengan menimbang hasil panen pada masing-masing bedeng. Total bobot hasil panen buah terung tiap bedeng yang disajikan pada Gambar 6.

Pada Gambar 6 dapat diketahui produktivitas tertinggi pada perlakuan P4B1 dengan rata-rata berat tiap buah terung sebesar 200,35 gram, sedangkan produktivitas terendah terdapat pada perlakuan P1B3 dengan berat rata-rata tiap buah sebesar 87,71 gram. Hal tersebut dipengaruhi oleh beberapa faktor misalnya hama tanaman dan tanaman yang belum berbuah. Menurut Muldiana dan Rosidana (2017), pertumbuhan buah membutuhkan zat hara utama yaitu nitrogen, fosfor dan kalium. Jika zat tersebut kurang terpenuhi akan mengganggu pertumbuhan buah. Nitrogen diperlukan untuk pembentukan protein, fosfor untuk pembentukan sel baru serta mempercepat pertumbuhan bunga, buah dan biji. Sedangkan kalium berfungsi untuk memperlancar pengangkutan karbohidrat dan pembelahan sel sehingga mempengaruhi pembentukan serta pertumbuhan buah hingga masak.

\subsubsection{Penggunaan Pestisida Organik Botanik}

Hama yang paling banyak menyerang tanaman terung adalah penggerek daun dan ulat grayak. Oleh karena itu digunakan pestisida botanik yang terbuat dari daun trembesi, daun mimba, daun sirsak dan MOL (mobilin). Pohon mimba diketahui memiliki berbagai bahan aktif yang bersifat insektisida sehingga cocok digunakan untuk pengelolaan hama terpadu karena toksisitasnya yang rendah terhadap organisme non target Senyawa aktif yang terkandung dalam tanaman mimba tidak dapat membunuh hama dengan cepat, namun berpengaruh pada daya makan, pertumbuhan, daya reproduksi, proses ganti kulit, menghambat perkawinan, penurunan daya tetas tekur dan berfungsi 
sebagai pemandul. Hal tersebut mengakibatkan jumlah daun terung yang mati karena serangan hama tersebut masih cukup tinggi karena dosis paling tinggi yaitu B4 (11 ml/liter) belum cukup untuk menekan pertumbuhan hama penggerek dan dan ulat grayak (Wibawa, 2019). Hama yang menyerang daun tanaman terung dapat dilihat pada Gambar 7.

\subsection{Analisis kualitas tanah}

Analisis dilakukan dengan mengukur sifat fisik dan kimia tanah. Pada sifat fisik tanah dilakukan pengukuran tekstur, struktur, dan permeabilitas tanah. Sedangkan pada sifat kimia tanah dilakukan pengukuran C-organik tanah yang mana digunakan untuk menghitung nilai bahan organik yang terkandung di dalam tanah.

\subsubsection{Tekstur Tanah}

Analisis tekstur tanah memiliki tujuan untuk menentukan perbandingan antara fraksi tanah. Hasil analisis tekstur tanah dapat dilihat pada Tabel 3. Berdasarakan Tabel 3 dapat diketahui kelas tesktur tanah pada lokasi penelitian sebelum diberi perlakuan masuk kedalam kelas tekstur lempung, sedangkan setelah diberi perlakuan secara umum didominasi oleh kategaori lempung berpasir kecuali perlakuan K2P3 dan K2P4. Tekstur tanah lempung memiliki kapasitas untuk menyerap unsur hara yang lebih baik dari pasir. Setelah pemberian perlakuan, tekstur tanah menjadi lempung berpasir dengan ciri rasa agak kasar, membentuk bola agak keras tetapi mudah hancur dan melekat (Mulyono et al., 2019).

\subsubsection{Struktur Tanah}

Analisis struktur tanah dilakukan sebanyak 3 kali yaitu pada saat pengambilan tanah pertama (K1), pengambilan tanah kedua (K2), dan pengambilan tanah (K3). Hasil pengujian struktur tanah dapat dilihat pada Tabel 4. Berdasarkan Tabel 4 menunjukkan bahwa tanah di wilayah Sub-DAS Arjasa memiliki tipe struktur blocky dengan kode penilaian 4 dan masuk ke dalam struktur gumpal kasar (ukuran $20-50 \mathrm{~mm}$ ). Derajat struktur tanah dari sampel tanah termasuk sedang karena memilki agregat yang jelas terbentuk dan masih dapat dipecahkan. Nilai dari 3 kali pengukuran tersebut mengalami peningkatan diameter mulai dari sebelum diberi
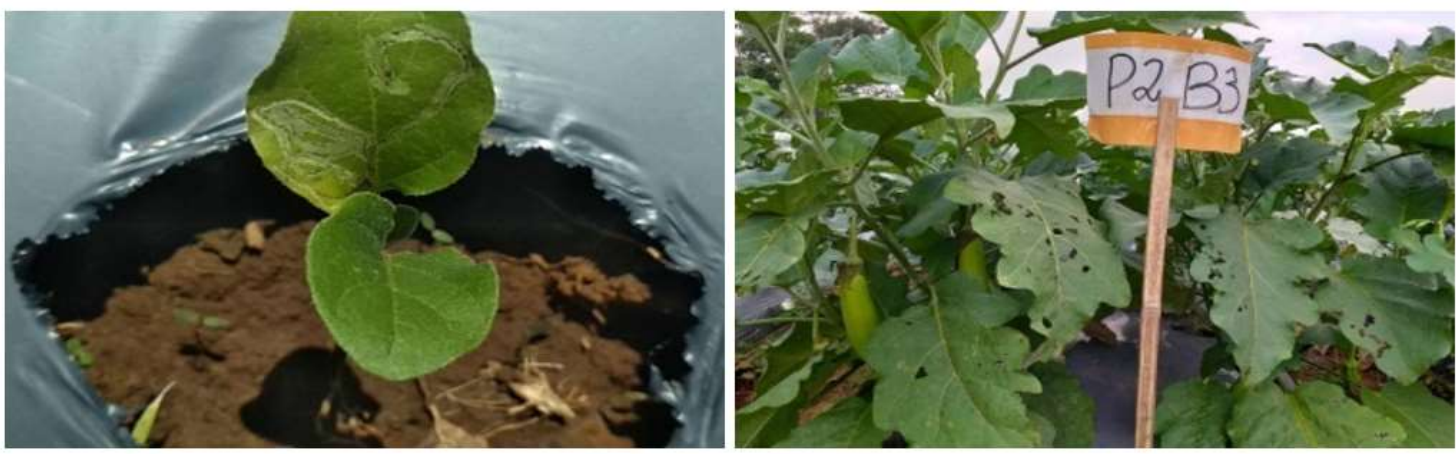

Gambar 7. Serangan Hama Penggerek (kiri) dan Ulat (kanan) pada Daun Terung

Tabel 3. Data Analisis Tekstur Tanah

\begin{tabular}{ccccc}
\hline \multirow{2}{*}{ Sample } & \multicolumn{3}{c}{ Fraksi Tanah (\%) } & \multirow{2}{*}{ Kelas Tekstur } \\
\cline { 2 - 4 } & Pasir & Liat & Debu & \\
K1 & 51,24 & 16,03 & 32,73 & Loam \\
K2P1 & 52,87 & 16,22 & 30,91 & Sandy Loam \\
K2P2 & 52,66 & 15,18 & 32,16 & Sandy Loam \\
K2P3 & 50,95 & 16,12 & 32,93 & Loam \\
K2P4 & 51,01 & 16,1 & 32,89 & Loam \\
K3P1 & 57,00 & 12,07 & 30,39 & Sandy Loam \\
K3P2 & 59,23 & 12,08 & 28,69 & Sandy Loam \\
K3P3 & 63,62 & 10,99 & 25,39 & Sandy Loam \\
K3P4 & 58,15 & 10,94 & 30,91 & Sandy Loam \\
\hline
\end{tabular}


pupuk, pemupukan pertama hingga pemupukan kedua. Pada saat pengamatan secara langsung sampel tanah menyerupai kubus dengan sudutsudut membulat Hal tersebut yang menyebabkan tipe struktur disebut blocky. Tanah dengan tipe blocky atau columnar bersifat mudah menyerap air namun susah meloloskan air serta tidak mudah ditembus akar. Tanah seperti ini bersifat lempung dan drainase yang buruk (Ayuningtyas et al., 2018).

Pengaplikasian pupuk organik berangsur-angsur akan mengalami dekomposisi dan menghasilkan humus. Interaksi antara humus dengan partikel tanah akan menghasilkan ruang pori yang lebih besar dan struktur yang lebih mantap (Zulkarnain, 2013).

\subsubsection{Permeabilitas Tanah}

Nilai permeabilitas digunakan untuk menganalisis kemampuan tanah untuk meloloskan air Hasil analisis permeabilitas tanah dapat dilihat pada Tabel 5. Berdasarkan hasil pengamatan yang ditunjukkan oleh Tabel 5 dapat diketahui bahwa sebelum diberi perlakuan atau K1 nilai rata-rata permeabilitas dari ketiga ulangan sebesar 2,959 cm/jam dan masuk ke dalam kelas 4 yang berarti tingkat permeabilitasnya lambat sampai sedang. Setelah diberi perlakuan dilakukan pengukuran $\mathrm{K} 2$ dan diperoleh nilai rata-rata permeabilitas $\mathrm{P} 1(7,32 \mathrm{~cm} / \mathrm{jam}), \mathrm{P} 2$ (7,12 cm/jam), P3 (14,84 cm/jam), dan P4 (1,62 $\mathrm{cm} /$ jam). Perlakuan P1 dan P2 masuk ke dalam kelas 3 dengan tingkat permeabilitas sedang, sedangkan P3 masuk ke dalam kelas 2 dengan

Tabel 4. Data Analisis Struktur Tanah

\begin{tabular}{cccccc}
\hline Kode & $\begin{array}{c}\text { Sub } \\
\text { DAS }\end{array}$ & Sampel & $\begin{array}{c}\text { Ukuran Struktur } \\
(\mathbf{m m})\end{array}$ & Bentuk Struktur & Kode Penilaian \\
\hline K1 & Arjasa & Tanah Terusik & 30,00 & Blocky & 4 \\
\hline K2P1 & & & 35,00 & & 4 \\
K2P2 & \multirow{2}{*}{ Arjasa } & Tanah Terusik & 43,00 & Blocky & 4 \\
K2P3 & & & 29,00 & & 4 \\
K2P4 & & 38,00 & & 4 \\
\hline K3P1 & & & 30,00 & 4 \\
K3P2 & \multirow{2}{*}{ Arjasa } & Tanah Terusik & 34,00 & Blocky & 4 \\
K3P3 & & & 34,00 & & 4 \\
K3P4 & & 38,00 & & 4 \\
\hline
\end{tabular}

Tabel 5. Data Analisis Permeabilitas Tanah

\begin{tabular}{|c|c|c|c|c|c|c|c|c|c|}
\hline \multirow[t]{2}{*}{ Kode } & \multicolumn{3}{|c|}{$\begin{array}{c}\text { Nilai Pengulangan } \\
(\mathrm{ml})\end{array}$} & \multirow[t]{2}{*}{ K1 } & \multirow[t]{2}{*}{ K2 } & \multirow[t]{2}{*}{ K3 } & \multirow{2}{*}{$\begin{array}{c}\text { Rata- } \\
\text { rata }\end{array}$} & \multirow[t]{2}{*}{ Kelas } & \multirow{2}{*}{$\begin{array}{c}\text { Tingkat } \\
\text { Permeabilitas }\end{array}$} \\
\hline & Q1 & Q2 & Q3 & & & & & & \\
\hline K1 & 27,8 & 32 & 36 & 2,58 & 10,93 & 3,33 & 2,96 & 4 & $\begin{array}{c}\text { Lambat sampai } \\
\text { sedang }\end{array}$ \\
\hline K2P1 & 95 & 70 & 72 & 8,80 & 6,49 & 6,67 & 7,32 & 3 & Sedang \\
\hline K2P2 & 51,5 & 84 & 95 & 4,77 & 7,78 & 8,80 & 7,12 & 3 & Sedang \\
\hline K2P3 & 148 & 172 & 160,5 & 13,7 & 15,94 & 14,87 & 14,84 & 2 & $\begin{array}{l}\text { Sedang sampai } \\
\text { cepat }\end{array}$ \\
\hline K2P4 & 22 & 18,5 & 12 & 2,04 & 1,71 & 1,11 & 1,62 & 5 & Lambat \\
\hline K3P1 & 24 & 36 & 22 & 2,22 & 3,34 & 2,04 & 2,53 & 4 & $\begin{array}{c}\text { Lambat sampai } \\
\text { sedang }\end{array}$ \\
\hline K3P2 & 30 & 24,5 & 25 & 2,78 & 2,27 & 2,32 & 2,46 & 4 & $\begin{array}{c}\text { Lambat sampai } \\
\text { sedang }\end{array}$ \\
\hline КЗР3 & 57 & 69 & 72 & 5,28 & 6,39 & 6,67 & 6,11 & 4 & $\begin{array}{c}\text { Lambat sampai } \\
\text { sedang }\end{array}$ \\
\hline K3P4 & 20 & 24 & 20,5 & 1,85 & 2,22 & 1,90 & 1,99 & 5 & Lambat \\
\hline
\end{tabular}


permeabilitas sedang sampai cepat dan P4 masuk ke dalam kelas 5 dengan permeabilitas lambat. Pada perlakuan $\mathrm{K} 3$ memiliki rata-rata permeabilitas P1 (2,53 cm/jam), P2 $(2,46 \mathrm{~cm} /$ jam), P3 (6,11 cm/jam) dan P4 (1,99 cm/jam). Perlakuan P1, P2 dan P3 mmasuk ke dalam kelas 4 yang berarti permeabilitasnya lambat sampai sedang dan untuk P4 masuk ke dalam kelas 5 dengan permeabilitas lambat. Hasil yang diperoleh dari pengukuran tersebut tidak signifikan dengan tingkat permeabilitas sedang hingga lambat.

Menurut Ayuningtyas et al. (2018) laju permeabilitas lambat disebabkan oleh kandungan lempung yang tinggi sehingga infiltrasi terjadi sangat lambat yang berdampak pada tingginya runoff dan cepatnya tanah untuk jenuh yang berakibat pada longsor. Menurut Mulyono et al. (2019) terdapat beberapa faktor yang mempengaruhi tingkat permeabilitas tanah terutama tekstur, struktur, stabilitas agregat, porositas distribusi ukuran pori, kontinyuan pori dan kandungan bahan organik. Nilai permeabilitas tanah akan meningkat jika agregasi butir tanah remah, terdapat saluran bekas lubang akar tanaman yang terdekomposisi, terdapat bahan organik serta porositas tanah yang tinggi (Mulyono et al. 2019). Peningkatan dosis pupuk organik pada setiap perlakuan mengakibatkan penurunan permeabilitas tanah. Hal tersebut sesuai dengan data yang diperoleh pada Tabel 6 yaitu penggunaan pupuk P4 memiliki nilai permeabilitas yang lebih kecil jika dibandingkan dengan perlakuan $\mathrm{P}$.

\subsubsection{Analisis Bahan Organik Tanah (BO)}

Hasil analisis bahan organik tanah ditampilkan pada Tabel 6. Berdasarkan data BO pada tabel 6 dapat diketahui bahwa nilai bahan organik setelah pemberian pupuk ada yang meningkat dan ada yang menurun. Sebelum perlakuan diperoleh nilai bahan organik masuk kedalam kelas 3 yang berarti tinggi. Setelah pemberian pupuk pertama (pengambilan sampel tanah kedua atau K2), terjadi penurunan kadar bahan organik perlakuan P1, P3 dan P4 namun tetap masuk kedalam kelas 3, sedangkan untuk P2 terjadi penurunan hingga masuk kedalam kelas 2 yang berarti nilai bahan organiknya sedang. Pada pengambilan sampel tanah $K 3$ terjadi penurunan pada perlakukan P1 hingga masuk kedalam kelas 2, sedangkan untuk perlakuan P2, P3 dan P4 terjadi peningkatan kadar bahan organik namun tidak terlalu tinggi.

Kandungan C-organik tanah sebelum diberi perlakuan (K1) memiliki nilai yang lebih rendah jika dibandingkan dengan pengukuran $K 3$. Pemberian pupuk organik pada tanah diperlukan untuk memepertahankan serta meningkatkan kandungan C-organik di dalam tanah (Adijaya dan Yasa, 2014). Bahan organik yang diaplikasikan pada tanah mengalami proses dekomposisi yang berperan sebagai perekat dalam proses agregasi tanah (Zulkarnain et al., 2013).

Bahan organik tidak hanya berperan menyusun tanah pada tekstur lempungan, tetapi juga memiliki peranan penting pada tekstur pasiran. Proporsi tanah pasiran yang besar $(>0,06 \mathrm{~mm})$

Tabel 6. Data Analisis Bahan Organik Tanah (BO)

\begin{tabular}{ccccccc}
\hline Kode & $\begin{array}{c}\text { Sub } \\
\text { DAS }\end{array}$ & Sampel & C-Organik (\%) & $\begin{array}{c}\text { Bahan } \\
\text { Organik (\%) }\end{array}$ & Kelas & $\begin{array}{c}\text { Kriteria Bahan } \\
\text { Organik }\end{array}$ \\
\hline K1 & & & 1,257 & 2,167 & 3 & Tinggi \\
P1K2 & & 1,226 & 2,114 & 3 & Tinggi \\
P2K2 & & 1,149 & 1,981 & 2 & Sedang \\
P3K2 & & 1,189 & 2,050 & 3 & Tinggi \\
P4K2 & \multirow{2}{*}{ Arjasa } & Tanah & 1,168 & 2,014 & 3 & Tinggi \\
P1K3 & & Terusik & 1,156 & 1,994 & 2 & Sedang \\
P2K3 & & 1,203 & 2,073 & 3 & Tinggi \\
P3K3 & & 1,477 & 2,547 & 3 & Tinggi \\
P4K3 & & 1,182 & 2,037 & 3 & Tinggi \\
\hline
\end{tabular}


miskin akan pori-pori mikro sehingga cepat mengalami kekeringan. Tingginya kandungan bahan organik maka mikropori akan meningkat sehingga kapasitas menyimpan air pada tanah pasiran lebih maksimal (Ayuningtyas et al., 2018). Tanah yang banyak mengandung bahan organik akan lebih terbuka sehingga aerasi tanah lebih baik serta tidak mudah mengalami pemadatan (Sutanto, 2002). Pemberian bahan organik dapat membentuk ruang pori mikro menjadi lebih banyak sehingga ketersediaan air dalam tanah juga semakin banyak. Hal tersebut dikarenakan ruang pori mikro berfungsi untuk mengikat air (Hasibuan, 2015). Setelah analisis beberapa parameter yang dibutuhkan untuk menetukan erodibilitas tanah $(K)$ selesai. Data hasil analisis erodibilitas tanah $(K)$ ditampilkan pada Tabel 7.

Berdasarkan Tabel 7 dapat diketahui bahwa nilai erodibilitas tanah mengalami kenaikan setelah diberi perlakuan pupuk organik. Erodibilitas tanah berkaitan dengan agregat tanah. Agregat merupakan partikel tanah yang melekat antara satu dengan lainnya membentuk unit yang lebih besar. Faktor yang dapat menurunkan agregat tanah antara lain pengolahan tanah berlebih dan sistem pertanian tanaman semusim. Tanah dengan nilai erodibilitas yang tinggi dengan curah hujan yang sama akan mudah tererosi jika dibandingkan dengan tanah dengan tingkat erodibilitas rendah. nilai erodibilitas ditentukan oleh ketahanan tanah terhadap gaya rusak dari luar maupun kemampuan tanah untuk menyerap air (Andawayanti, 2019).

\subsection{Prediksi Laju Erosi Menggunakan Metode USLE}

Penentuan laju erosi dilakukan dengan menghitung setiap faktor menggunakan Persamaan 7. Hasil yang diperoleh diklasifikasikan berdasarkan kelas tingkat bahaya erosi. Data ditampilkan pada Tabel 8. Berdasarkan hasil analisis pada Tabel 8 dapat diketahui tingkat bahaya erosi di wilayah SubDAS Arjasa termasuk ke dalam kelas III yang berarti sedang. Terjadi peningkatan tingkat

Tabel 7. Data Analisis Erodibilitas Tanah $(K)$

\begin{tabular}{cccccccc}
\hline No & Sampel & $\begin{array}{c}\text { \%Debu + } \\
\text { Pasir Halus }\end{array}$ & $\begin{array}{c}\text { \%Pasir } \\
\text { kasar }\end{array}$ & $\begin{array}{c}\text { B- } \\
\text { Organik }\end{array}$ & $\begin{array}{c}\text { Struktur } \\
\text { Tanah }\end{array}$ & $\begin{array}{c}\text { Permeabilitas } \\
\text { Tanah }\end{array}$ & $\begin{array}{c}\text { Erodibilitas } \\
\text { Tanah }\end{array}$ \\
\hline 1 & K1 & 70,72 & 13,25 & 3 & 4 & 4 & 0,59 \\
2 & K2 P1 & 82,21 & 1,57 & 3 & 4 & 3 & 0,55 \\
3 & K2 P2 & 82,84 & 1,98 & 2 & 4 & 3 & 0,62 \\
4 & K2 P3 & 82,58 & 1,30 & 3 & 4 & 2 & 0,52 \\
5 & K2 P4 & 81,68 & 2,22 & 3 & 4 & 5 & 0,69 \\
6 & K3 P1 & 85,95 & 1,44 & 2 & 4 & 4 & 0,67 \\
7 & K3 P2 & 83,85 & 1,08 & 3 & 4 & 4 & 0,61 \\
8 & K3 P3 & 87,21 & 1,80 & 3 & 4 & 4 & 0,64 \\
9 & K3 P4 & 87,56 & 1,50 & 3 & 4 & 5 & 0,68 \\
\hline
\end{tabular}

Tabel 8. Data Pengamatan Tingkat Bahaya Erosi Menggunakan Metode USLE

\begin{tabular}{ccccccc}
\hline Sampel & $\boldsymbol{R}$ & $\boldsymbol{K}$ & $\boldsymbol{L} \boldsymbol{C}$ & $\boldsymbol{C P}$ & $\boldsymbol{A}$ & TBE \\
\hline K1 & 879,7631 & 0,58 & 0,952 & 0,1936 & 94,0757 & III \\
K2 P1 & 879,7631 & 0,55 & 0,952 & 0,1936 & 89,2097 & III \\
K2 P2 & 879,7631 & 0,62 & 0,952 & 0,1936 & 100,5637 & III \\
K2 P3 & 879,7631 & 0,52 & 0,952 & 0,1936 & 84,3437 & III \\
K2 P4 & 879,7631 & 0,62 & 0,952 & 0,1936 & 100,5637 & III \\
K3 P1 & 879,7631 & 0,68 & 0,952 & 0,1936 & 110,2957 & III \\
K3 P2 & 879,7631 & 0,60 & 0,952 & 0,1936 & 97,3197 & III \\
K3 P3 & 879,7631 & 0,64 & 0,952 & 0,1936 & 103,8077 & III \\
K3 P4 & 879,7631 & 0,68 & 0,952 & 0,1936 & 110,2957 & III \\
\hline
\end{tabular}


bahaya erosi setelah perlakuan pupuk organik yang disebabkan oleh peningkatan nilai erodibilitas. Hal tersebut terjadi karena erodibilitas berkaitan dengan agregat tanah serta meningkatnya kandungan pasir pada pengukuran K1, K2, dan K3. Agregat merupakan partikel tanah yang melekat antara satu dengan lainnya membentuk unit yang lebih besar. Namun peningkatan laju erosi tersebut tidak sinifikan karena masih berada pada tingkat bahaya erosi yang sama. Faktor yang dapat menurunkan agregat tanah antara lain pengolahan tanah berlebih dan sistem pertanian tanaman semusim. Tanah dengan nilai erodibilitas yang tinggi akan peka terhadap terjadinya erosi. Peningkatan laju erosi pada petak kebun ini hanya disebabkan perubahan karakteristik sifat fisik tanah akibat perbedaan dosis penggunaan pupuk organik, karena parameter yang lain seperti nilai R, C, P, L dan $\mathrm{S}$ adalah sama untuk masing-masing petak kebun.

\section{KESIMPULAN DAN SARAN}

\subsection{Kesimpulan}

Penggunaan pupuk organik berpengaruh nyata terhadap pertumbuhan tinggi tanaman dan jumlah daun tanaman terung, sedangkan penggunaan pestisida tidak berpengaruh nyata. Dosis paling efektif untuk terdapat pada perlakuan $\mathrm{P} 4$ dengan komposisi $2 \mathrm{~kg}$ pupuk organik (dengan asumsi $0,250 \mathrm{~kg} /$ tanaman). Untuk hasil panen yang paling optimum terdapat pada perlakuan P4B1 dengan komposisi $2 \mathrm{~kg}$ pupuk organik $(0,250 \mathrm{~kg} / \operatorname{tanaman})$. dan $2 \mathrm{ml} /$ liter pestisida kimia $(7,7 \mathrm{ml} /$ tanaman). Penggunaan pestisida kimia lebih efisien untuk hasil panen karena lebih efektif menangani hama penggerek dan ulat grayak yang terdapat pada tanaman terung. Terjadi peningkatan kualitas tanah di lahan pertanian Sub-DAS Arjasa setelah pengaplikasian pupuk organik yang ditunjukan dengan produktivitas yang lebih baik dibandingkan penggunaan pupuk kimia. Perubahan tersebut diantaranya tekstur tanah loam menjadi sandy loam yang disebabkan oleh peninggkatan kandungan fraksi pasir halus sehingga permeabilitas menjadi lambat, dan bahan organik tinggi menjadi sedang sampai tinggi. 3. Perbaikan sifat fisik tanah menyebabkan peningkatan nilai erodibilitas tanah sehinga mampu meningkatan nilai erosi, namun peningkatan tersebut tidak berbeda secara signifikan dimana masih masuk dalam kelas tingkat bahaya erosi yang sama, yaitu sedang (III).

\subsection{Saran}

Perlu dilakukan penelitian lebih lanjut dengan metode yang sama dalam durasi waktu yang lebih lama untuk mengetahi pengaruhnya dalam jangka waktu lama.

\section{UCAPAN TERIMA KASIH}

Penelitian ini didanai dari Hibah Internal skema Pendamping IDB tahun 2020.

\section{DAFTAR PUSTAKA}

Adijaya, I.N. dan Yasa, I.M.R. 2014. Pengaruh pupuk organik terhadap sifat tanah, pertumbuhan dan hasil jagung. Prosiding Seminar Nasional "Inovasi Teknologi Pertanian Spesifik Lokasi”. 6-7 Agustus 2014. Balai Pengkajian Teknologi Pertanian (BPTP). Bali. 299-310.

Adnyana, I.M. 2011. Peningkatan kualitas tanah dalam mewujudkan produktivitas lahan pertanian secara berkelanjutan. Bumi Lestari Journal of Environment, 11(1): 131-137.

Andawayanti, U. 2019. Pengelolaan Daerah Aliran Sungai (DAS) Terintegrasi. Malang: UB Press.

Andriyani, I., Wahyuningsih, S. dan Suryaningtias, S. 2019. Perubahan tata guna lahan di Sub DAS Rembangan - Jember dan dampaknya terhadap laju erosi, Agritech, 39(2): 117127.

Andriyani, I., Jourdain, D., Lidon, B., Soni, P., and Kartiwa, B. 2017. Upland farming system erosion yields and their constraints to change for sustainable agricultural conservation practices: A case study of land use and land cover (LULC) change in Indonesia. Land Degrad. Develop., 28: 421430. doi: 10.1002/ldr.2598. 
Arsyad, S. 1989. Konservasi Tanah dan Air. Bogor: IPB Press.

Arsyad, S. 2010. Konservasi Tanah dan Air. Bogor: IPB Press.

Ayuningtyas, E.A., Ilma, A.F.N. dan Yudha, R.B. 2018. Pemetaan erodibilitas tanah dan korelasinya terhadap karakteristik tanah di DAS Serang, Kulonprogo. Jurnal Nasional Teknologi Terapan, 2(1): 37-46.

Balai Penelitian Tanah. 2005. Analisis Kimia Tanah, Tanaman, Air dan Pupuk. Bogor: Balai Penelitian Tanah.

Dewanto, F.G., Londok, J.J.M.R. dan Tuturoong, R.A.V. 2013. Pengaruh pemupukan anorganik dan organik terhadap produksi tanaman jagung sebagai sumber pakan. Jurnal Zootek. 32(5): 1-8.

Hanafiah, K. A. 2014. Dasar-Dasar Ilmu Tanah. Jakarta: Rajawali Press.

Hasibuan, A. S. Z. 2015. Pemanfaatan bahan organik dalam perbaikan beberapa sifat tanah pasir Pantai Selatan Kulon Progo. Planta Tropika Journal of Agro Science, 3(1): 31-40.

Kartasapoetra, A. G. dan M. Sutedjo. 1991. Pengantar Ilmu Tanah Terbentuknya Tanah dan Tanah Pertanian. Jakarta: Rineka Cipta.

Lakitan, B. 2011. Dasar-Dasar Fisiologi Tumbuhan. Jakarta: Raja Grafindo Persada.

Muldiana, S. dan Rosdiana. 2017. Respon tanaman terong (Solanum malongena L.) terhadap interval pemberian pupuk organik cair dengan interval waktu yang berbeda. Prosiding Pertanian dan Tanaman Herbal Berkelanjutan di Indonesia. 8 November 2017. Fakultas Pertanian, Universitas Muhammadiyah Jakarta. 155-162.

Mulyono, A., Lestiana, H. dan Fadillah, A. 2019. Permeabilitas tanah berbagai tipe penggunaan lahan di tanah aluvial pesisir DAS Cimanuk, Indramayu. Jurnal Ilmu Lingkungan, 17(1): 1-6.
Santoso, B., Hendrijanto, K., Rahmawati, A., Jannah, R. dan Tyas, M.R. 2013. Model intervensi pengelolaan Daerah Aliran Sungai (DAS) (Community Based Action Research) pada masyarakat di Daerah Aliran Sungai Bedadung Kabupaten Jember). Jember: Program Studi Sosiologi FISIP Universitas Jember.

Simanjuntak, A., Lahay, R.R. dan Purba, E. 2013. Respon pertumbuhan dan produksi bawang merah (Allium ascalonicum L.) terhadap pemberian pupuk NPK dan kompos kulit buah kopi. Jurnal Online Agroekoteknologi, 1(3): 362-373.

Sumarmo. 2014. Konsep pertanian modern, ekologis, dan berkelanjutan. Dalam Reformasi Kebijakan Menuju Transformasi Pembangunan Pertanian. Editor: Haryono, E. Pasandaran, M. Rachmat, S. Mardianto, Sumedi, H.P. Salim dan A. Hendriadi. Badan Penelitian Dan Pengembangan Pertanian, Kementerian Pertanian: 33-59.

Supriadi, B. 2019. 65 Persen DAS Bedadung kritis, berpotensi banjir. https:// radarjember.jawapos.com/berita-daerah/ jember/24/12/2019/65-persen-dasbedadung-kritis-berpotensi-banjir/. [Diakses pada 29 Juni 2020].

Sutanto, R. 2002. Penerapan Pertanian Organik Pemasyarakatan dan Pengembangannya. Yogyakarta: Kanisius.

Undang-undang Nomor 7.2004. Undang-undang Nomor 7 Tahun 2004 tentang Sumberdaya Air. Pemerintah Republik Indonesia: Jakarta.

Wahyunto dan Dariah, A. 2014. Degradasi lahan di Indonesia: Kondisi existing, karakteristik, dan penyeragaman definisi mendukung gerakan menuju satu peta. Jurnal Sumberdaya Lahan, 8(2): 81-93.

Wibawa, I.P.A.H. 2019. Uji efektivitas ekstrak mimba (Azadirachta indica A. Juss.) untuk mengendalikan hama penggerek daun pada 
tanaman Podocarpus neriifolius. E-Jurnal Agroekoteknologi Tropika, 8(1): 20-31.

Zulkarnain, M., Prasetya, B., dan Soemarno. 2013. Pengaruh kompos, pupuk kandang, dan custom-bio terhadap sifat tanah, pertumbuhan dan hasil tebu (Saccharum officinarum L.) pada Entisol di Kebun Ngrangkah-Pawon, Kediri). Indonesian Green Technology Journal, 2(1): 45-52. 